\title{
KöLN RADIOCARBON MEASUREMENTS II
}

\section{J C FREUNDLICH, H SCHWABEDISSEN, and W E WENDT}

${ }^{14} \mathrm{C}$ Laboratory, Institut für Ur- und Frühgeschichte, Universität zu Köln, D-5 Köln 41, West Germany

Since the publication of our first date list (R, 1966, v 8, p 239-247), our ${ }^{14} \mathrm{C}$ laboratory has produced about 1500 radiocarbon dates, including several hundreds of concordant double determinations, the majority of which were on archaeologic samples. The greater part of the other dates concerned dendrochronologic samples from our Tree Ring Laboratory (Schmidt, 1977; Freundlich, 1977). Several archaeologic dates have already been published in articles on archaeology, preferentially by the respective excavators, in a few instances also by us (eg, Schwabedissen and Freundlich, 1968; Faruggia et al, 1973; Kuper, 1975; Lüning and Zürn, 1977; Hohenschwert, 1978). An extensive compilation of Neolithic dates is in preparation.

We believe that it is not very promising just to compile lists of dates "from the shelf" without detailed descriptions of archaeologic samples and their widely differing traits, along with the context of the excavation site. Such "listed ages" would be almost meaningless, eg, Dümmer ( $c f$ Wendt et al, 1962, 106).

Chemical preparation of the samples and measurement procedures did not change essentially since our previous list. Only our final purification of carbon dioxide gas (Freundlich and Rutloh, 1972) was changed to a modified form of De Vries' copper method (see Vogel and Waterbolk, 1967). Table 1 shows the properties of our proportional counters.

TABLE 1

\begin{tabular}{clcccc}
\hline Set no. & $\begin{array}{c}\text { Anode } \\
\text { material }\end{array}$ & $\begin{array}{c}\text { Volume } \\
\text { (liter) }\end{array}$ & $\begin{array}{c}\text { Filling } \\
\text { pressure } \\
\text { (atm) }\end{array}$ & $\begin{array}{c}\text { Background } \\
\text { (cpm) }\end{array}$ & $\begin{array}{c}95 \% \text { NBS } \\
\text { standard } \\
(\mathrm{cpm})\end{array}$ \\
\hline I & copper & 2.0 & 0.9 & 8.5 & 11.8 \\
II & copper & 2.3 & 0.8 & 6.3 & 12.5 \\
III & guilded & 0.51 & 3.0 & 0.7 & 10.3 \\
IV & quartz & & 1.0 & 0.6 & 3.4 \\
& steel $(*)$ & 0.46 & 3.0 & 1.3 & 9.3 \\
\hline
\end{tabular}

* See Faltings, 1952.

Several minor effects (one described by Freundlich, 1972; cf also Neustupny, 1970) influenced some of our earlier dates. All of our previous dates were reviewed, recalculated and/or redetermined from the original sample. These doubly checked dates are marked with an "I." preceding the laboratory number. For numbers higher than KN-999 (or KN-I.999), this was no longer necessary.

Tolerance value given with each date represents the one sigma value as determined from results of radioactivity assay of sample, background, and contemporary standard. All dates are expressed in the BP scale $(=$ before AD 1950) using the Libby half-life of 5568 years. Concerning the cor- 
rections for De Vries' effect, the reader is referred to the literature, eg, Suess, 1970; Damon et al, 1972; Ralph et al, 1973; Olsson et al, 1974; Watkins, 1975; Damon et al, 1978.

All sites mentioned in the following date list have been excavated by author W E Wendt in collaboration with State Museum Windhoek, for a continuing archaeologic research program in South West Africa between 1968 and 1974.

\section{ACKNOWLEDGMENTS}

We are indebted to Deutsche Forschungsgemeinschaft, Bonn, for a grant that completely funded all the field research requirements, and to Stiftung Volkswagenwerk, Hannover, for funding part of our radiocarbon dating equipment. Erika Spiess did most of the sample preparations; Ing Pavel Velicky assisted in supervising and maintenance of the dating equipment. Peter Breunig helped decisively with documentation and correspondence.

\section{SAMPLE DESCRIPTIONS}

\section{A. Sites in $S W$ districts of $S W$ Africa}

\section{Apollo 11-Cave series, SW Africa}

Excavation, begun in 1969, continued in 1972, of cave in Upper Nuob River of W Huns Mts $\left(27^{\circ} 45^{\prime} \mathrm{S}, 17^{\circ} 06^{\prime} \mathrm{E}\right) 145 \mathrm{~km}$ SE of Aus, Lüderitz dist, SW Africa.

General Comment: cave contains longest and most complete sequence of cultural layers excavated so far in SW Africa; Africa's oldest dated works of art ("art mobilier") have also been discovered here. Forty ${ }^{14} \mathrm{C}$ dates have been obtained ( $27 \mathrm{KN}$ dates, $13 \mathrm{Pta}$ dates). In order to present all relevant data, a schematic sec of main cultural layers appears in Fig 1, showing positions of all dated samples in relation to each other and to interfaces. Laboratory numbers of all 40 dates are listed in Table 2.

Fuller details and interpretative material have already been pub (Vogel, ms in preparation; Wendt, 1972, p 20-22; 1974, p 1-42; 1976, p 511. Some dates pub earlier (Wendt, 1972, p 21-22) have been modified. Samples coll 1969 and 1972, subm 1970, 1973, 1974, and 1975 by W E Wendt.

KN-I.608. Apollo 11 P. 1

Concentrated charcoal lumps at 3 to $5 \mathrm{~cm}$ depth in $\mathrm{Sq} \mathrm{B} 8$ assoc with Upper Pottery Layer A (Fig 1, no. 2).

KN-I.846. Apollo 11 P. 18

$1460 \pm 55$

Nest with uncharred twigs at 6 to $10 \mathrm{~cm}$ depth in $\mathrm{Sq}$ B 8-9 assoc with Lower Pottery Lens B (Fig 1, no. 3).

KN-I.870. Apollo 11 P. 26 $1670 \pm 55$

Uncharred twigs and grass scattered in spit at 12 to $17 \mathrm{~cm}$ depth in Sq A $8 \mathrm{X}_{2}$ assoc with Lower Pottery Lens B (Fig 1, no. 4). 
TABLE 2

\begin{tabular}{|c|c|}
\hline $\begin{array}{l}\text { No. } \\
\text { in } \\
\text { Fig. } 1\end{array}$ & $\begin{array}{l}\text { Lab.- No. } \\
\text { of } \\
\text { sample }\end{array}$ \\
\hline 1 & Pta-1009 \\
\hline 2 & KN-I.608 \\
\hline 3 & KN-I.846 \\
\hline 4 & KN-I.870 \\
\hline 40 & Pta-1918 \\
\hline 5 & KN-I.609 \\
\hline 6 & Pta-1019 \\
\hline 7 & KN-I.867 \\
\hline 8 & Pta-1020 \\
\hline 9 & KN-I.610 \\
\hline 10 & $\mathrm{KN}-\mathrm{I} .611$ \\
\hline 11 & Pta-1021 \\
\hline 12 & Pta-1010 \\
\hline 13 & KN-I.614 \\
\hline 14 & KN-I.811 \\
\hline 15 & KN-I.612 \\
\hline 16 & KN-I.613 \\
\hline 17 & $\bar{P}+\overline{-10}-\overline{9}$ \\
\hline 18 & KN-2057 \\
\hline 19 & KN-I.812 \\
\hline 20 & Pta-1040 \\
\hline 21 & KN-I. 813 \\
\hline 22 & $\mathrm{KN}-2056$ \\
\hline$-\frac{-}{23}$ & $\overline{\mathrm{K}} \overline{\mathrm{N}}-\overline{21} \overline{15}$ \\
\hline 24 & Pta-1032 \\
\hline 25 & KN-I.869 \\
\hline 26 & Pta-104l \\
\hline 27 & KN-I.847 \\
\hline 39 & Pta-1415 \\
\hline 28 & KN-I.615 \\
\hline 29 & Pta-507 \\
\hline 30 & KN-I.623 \\
\hline 31 & KN-I.616 \\
\hline 32 & KN-I.622 \\
\hline 33 & KN-I.620 \\
\hline 34 & Pta-505 \\
\hline 35 & KN-I.617 \\
\hline 36 & KN-I.618 \\
\hline 37 & KN-I.621 \\
\hline 38 & KN-I.619 \\
\hline
\end{tabular}

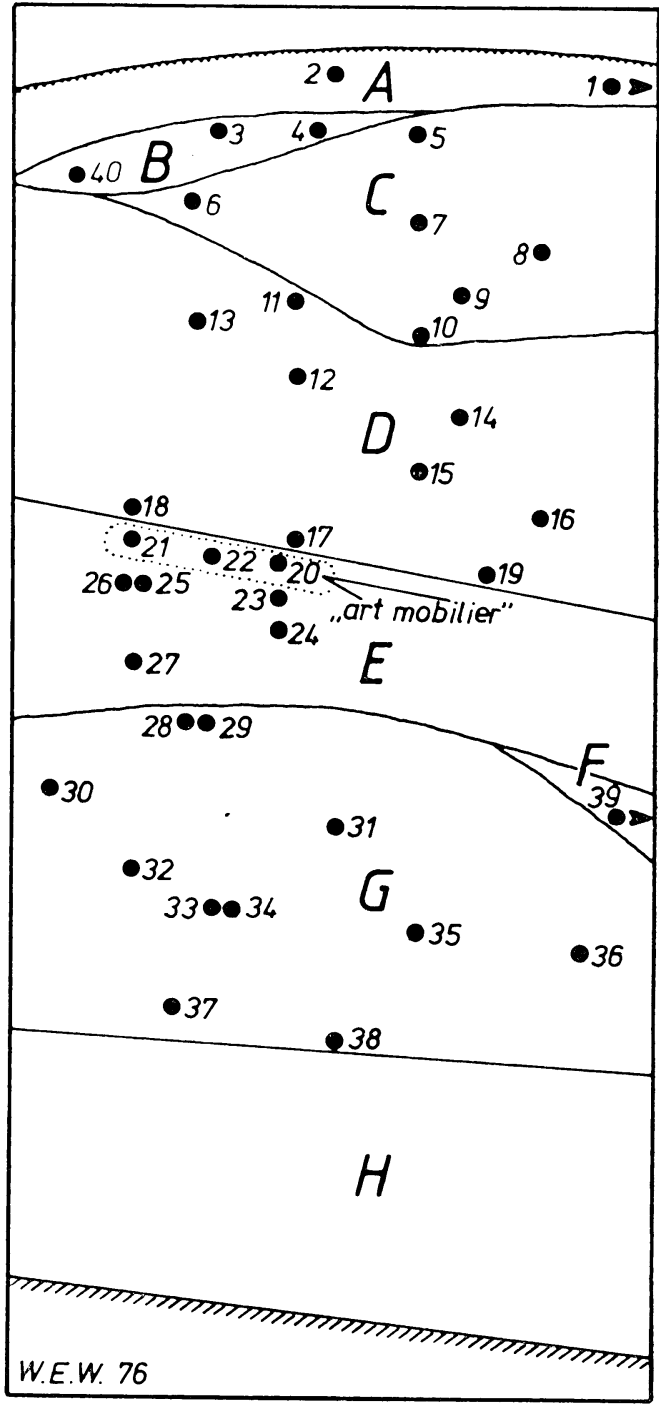

Fig. 1. Apollo 11-Cave: schematic section (not to scale) of main cultural layers, showing positions of all dated ${ }^{14} \mathrm{C}$ samples listed in Table 2 in relation to each other and to interfaces. 
Apollo 11-Cave: Main cultural layers

A: Upper pottery layer

Potsherds, wooden tools, crude stone artifacts, no typical microlithic tools. Few glass and iron beads on surface. Contacts with Europeans. ProtoHistoric.

B: Lower pottery lens

Contains earliest dated pottery excavated so far in S SW Africa. No typical microlithic tools.

$C$ : Later Stone age layer (LSA)

Typical, predominantly microlithic assemblage with convex scrapers, crescents, backed tools, only a few larger, scraper-like tools, worked ostrich eggshell (beads, engraved fragments), very few bone artifacts, seashell (fragments and pendants), pigments.

D: Early Later Stone age layer (ELSA)

Apparently consisting of 2 temporally distinct horizons. Essentially macrolithic assemblage, no typical microlithic tools. Ostrich eggshell beads occurring already in lowest horizon.

\section{E: Middle Stone age layer (MSA)}

Uppermost horizon still containing several blades. Layer ought to consist of several distinct horizons due to $>20,000 \mathrm{yr}$ apparently represented. Fragments of several painted slabs were recovered from "concentration" in uppermost horizon. Oldest dated art ("art mobilier") known on African continent.

I : Middle Stone age layer

Facies of blade industry, comprising a few backed blades, points and larger crescents. Affinities with Howieson's Poort? Only in outer portion of cave. Overlying Layer G.

G: Middle Stone age layer

Blade industry, on average larger than in Layer F. Most likely at least 2 main horizons distinguishable.

H: Basal Middle Stone age layer

Assemblage characterized by quite large points and flake-blades, but also some true blades found on bedrock. Only a few retouched artifacts. No datable matter preserved. 
KN-I.609. Apollo 11 P. $2 \quad 6200 \pm 65$

Concentrated charcoal lumps at 7 to $9 \mathrm{~cm}$ depth in $\mathrm{Sq} \mathrm{A} 7$ assoc with with upper horizon of LSA Layer C (Fig 1, no. 5).

KN-I.867. Apollo 11 P. 19

$7200 \pm 75$

Charcoal lumps from ashy lens at 23 to $26 \mathrm{~cm}$ depth in Sq A 7 assoc with deeper horizon of LSA Layer C (Fig 1, no. 7).

KN-I.610. Apollo 11 P. 3

$9430 \pm 90$

Scattered charcoal fragments at 28 to $32 \mathrm{~cm}$ depth in $\mathrm{Sq}$ A 7 assoc with deeper horizon of LSA Layer C (Fig 1, no. 9).

KN-I.611. Apollo 11 P. $4 \quad 10,420 \pm 80$

Charcoal lumps from ashy lens at 36 to $39 \mathrm{~cm}$ depth in $\mathrm{Sq} \mathrm{A} 7$ assoc with lowest horizon of LSA Layer C (Fig 1, no. 10).

KN-I.614. Apollo 11 P. 7

$13,030 \pm 100$

Charcoal lumps from ashy lens at 33 to $36 \mathrm{~cm}$ depth in $\mathrm{Sq}$ A 8 assoc with upper horizon of ELSA Layer D (Fig 1, no. 13).

KN-I.811. Apollo 11 P. 20

$13,470 \pm 125$

Charcoal lumps from ashy lens at 43 to $45 \mathrm{~cm}$ depth in $S q \mathrm{~A} 7$ assoc with deeper horizon of ELSA Layer D (Fig 1, no. 14).

KN-I.612. Apollo 11 P. 5

$13,690 \pm 120$

Nest with uncharred twigs at 54 to $57 \mathrm{~cm}$ depth in Sq A 7 assoc with deeper horizon of ELSA Layer D (Fig 1, no. 15).

KN-I.613. Apollo 11 P. 6 $14,550 \pm 60$

Charcoal lumps from ashy lens at 55 to $57 \mathrm{~cm}$ depth in Sq A 7 assoc with deeper horizon of ELSA Layer D (Fig 1, no. 16).

KN-2057. Apollo 11 P. 28

$18,660 \pm 210$

Uncharred twigs and charcoal fragments scattered in spit at 39 to $47 \mathrm{~cm}$ depth in Sq A $9 \mathrm{X}_{2}$ assoc with lowest horizon of ELSA Layer D (Fig 1, no. 18).

KN-I.812. Apollo 11 P. 22 $19,760 \pm 175$

Scattered charcoal lumps at 74 to $76 \mathrm{~cm}$ depth in Sq B 7-8 assoc with lowest horizon of ELSA Layer D (Fig 1, no. 19).

KN-I.813. Apollo 11 P. 23

$26,700 \pm 650$

Uncharred twigs, leaves, and grass from small volume of spit at 46 to $52 \mathrm{~cm}$ depth in $\mathrm{Sq}$ A $9 \mathrm{X}_{2}$ assoc with uppermost horizon of MSA Layer $\mathrm{E}$ and surrounding one of painted slabs (Fig 1, no. 21), (Wendt, 1974, Fig 18-19).

KN-2056. Apollo 11 P. 27

$28,400 \pm 450$

Uncharred twigs and charcoal fragments scattered in spit at 54 to $60 \mathrm{~cm}$ depth in Sq A $9 \mathrm{X}_{1}$ assoc with uppermost horizon of MSA Layer $\mathrm{E}$ 
and close to another painted slab (Fig 1, no. 22), (Wendt, 1974, p 35, Fig 18-20).

KN-2115. Apollo 11 P. 29

$32,700 \pm 860$

Uncharred twigs and grass scattered in spit at 64 to $70 \mathrm{~cm}$ depth in $\mathrm{Sq}$ A $8 \mathrm{X}_{2}$ assoc with deeper horizon of MSA Layer $\mathrm{E}$ and well below horizon with "art mobilier" (Fig 1, no. 23).

KN-I.869. Apollo 11 P. 24

$\mathbf{3 3 , 3 7 0} \pm \mathbf{5 5 0}$

Uncharred twigs from small volume of spit at 53 to $59 \mathrm{~cm}$ depth in $\mathrm{Sq}_{1}$ A $9 \mathrm{X}_{2}$ assoc with deeper horizon of MSA Layer $\mathrm{E}$ and directly below spit with 2 painted slabs (Fig 1, no. 25). Comment: sample was divided at random; the other portion was dated at Pretoria (Pta-1041, Vogel, ms in preparation; Wendt, 1974, p 35, Fig 18-20).

KN-I.847. Apollo 11 P. 25

Nest with uncharred twigs and grass at 58 to $65 \mathrm{~cm}$ depth in $\mathrm{Sq}$ A 9 $\mathrm{X}_{2}$ assoc with deepest horizon of MSA Layer E (Fig 1, no. 27).

KN-I.615. Apollo 11 P. 8 $>49,000$

Nest with charred twigs and grass at 42 to $49 \mathrm{~cm}$ depth in $\mathrm{Sq}$ A 10 assoc with uppermost horizon of MSA Layer G (Fig 1, no. 28).

KN-I.623. Apollo 11 P. 16

Nest with charred grass at 67 to $72 \mathrm{~cm}$ depth in $\mathrm{Sq}$ A 12 assoc with upper horizon of MSA Layer G (Fig 1, no. 30).

KN-I.616. Apollo 11 P. 9

Charcoal lumps from ashy lens at 67 to $69 \mathrm{~cm}$ depth in $\mathrm{Sq}$ A 9 assoc with upper horizon of MSA Layer G (Fig 1, no. 31).

KN-I.622. Apollo 11 P. 15

Concentrated charcoal fragments at 99 to $102 \mathrm{~cm}$ depth in Sq A 11 assoc with deeper horizon of MSA Layer G (Fig 1, no. 32).

KN-I.620. Apollo 11 P. 13

Concentrated charcoal lumps at 81 to $83 \mathrm{~cm}$ depth in $\mathrm{Sq} A 11$ assoc with deeper horizon of MSA Layer G (Fig 1, no. 33).

KN-I.617. Apollo 11 P. 10 $>48,500$

Concentrated charcoal lumps at 93 to $95 \mathrm{~cm}$ depth in Sq A 9 assoc with deeper horizon of MSA Layer G (Fig 1, no. 35).

KN-I.618. Apollo 11 P. 11

Charcoal lumps from ashy lens at 116 to $118 \mathrm{~cm}$ depth in $\mathrm{Sq}$ A 9 assoc with deeper horizon of MSA Layer G (Fig 1, no. 36).

KN-I.621. Apollo 11 P. 14

Concentrated charcoal lumps at 110 to $116 \mathrm{~cm}$ depth in Sq A 11 assoc with even deeper horizon of MSA Layer G (Fig 1, no. 37). 
KN-I.619. Apollo 11 P. 12

Concentrated charcoal lumps at 114 to $117 \mathrm{~cm}$ depth in $\mathrm{Sq}$ A 10 assoc with deepest horizon of MSA Layer G (Fig 1, no. 38).

\section{Pockenbank series, SW Africa}

Excavation, 1969, of 2 test-pits in a cave on farm Pockenbank $\left(27^{\circ}\right.$ 19' S, $\left.16^{\circ} 31^{\prime} \mathrm{E}\right), 70 \mathrm{~km}$ SE of Aus, Lüderitz dist, SW Africa. Coll 1969 and subm 1970 by W E Wendt (Vogel, ms in preparation; Wendt, 1972, p 18-19).

General Comment: deposit, $2.2 \mathrm{~m}$ deep, contains at least 4 main layers that seem to correspond with Layers A, D, E, F and/or G in Apollo 11Cave. No true LSA layer was found in test pits although there are indications that such a layer might exist elsewhere in cave. The existing dates (5 more samples were dated at Pretoria: Pta-503,-504,-544,-1202,-1203) do not clearly indicate time beyond 30,000 BP. Layers are either very irregular or are disturbed. More extensive excavation is necessary. Basal layer containing typical MSA assemblage yielded no datable material. A few rock paintings were in the cave and numerous rock engravings occur in the vicinity.

KN-I.624. Pockenbank P. 1

$6910 \pm 45$

Charcoal fragments from ashy lens at 5 to $10 \mathrm{~cm}$ depth in $\mathrm{Sq}$ A 5 assoc with only a few atypical artifacts. Comment: although date falls well into range of LSA dates (see Apollo 11-Cave) no characteristic artifacts of such an assemblage were found so far.

KN-I.625. Pockenbank P. 2

$19,320 \pm 320$

Scattered fragments of charcoal at 52 to $54 \mathrm{~cm}$ depth in Sq A 7 assoc with only a few atypical macrolithic artifacts and worked ostrich eggshell. Comment: layer seems similar to Early Later Stone Age Layer D in Apollo 11-Gave.

KN-I.627. Pockenbank P. 4

Charcoal fragments from lens at 113 to $115 \mathrm{~cm}$ depth in Sq A 7 assoc with rather crude, atypical artifacts. Comment: sample could also represent an Early Later Stone age assemblage although date appears too early when compared with sequence from Apollo 11-cave.

KN-I.628. Pockenbank P. 5

$33,500 \pm 750$

Charcoal fragments from concentration at 131 to $134 \mathrm{~cm}$ depth in $\mathrm{Sq}$ A 7 assoc with several (snapped) blades and other artifacts of a MSA technology. Comment: sample can be compared to lower horizon of Layer $\mathrm{E}$ in Apollo 11-Cave.

KN-I.629. Pockenbank P. 6

Charcoal fragments from concentration at 84 to $87 \mathrm{~cm}$ depth in $\mathrm{Sq} \mathrm{A}$ 5 assoc with atypical artifacts, only slightly resembling MSA artifacts. Comment: relationship with Layer $\mathrm{E}$ in Apollo 11-Cave is possible but not well established. 
KN-I.626. Pockenbank P. 3

Charcoal fragments from lens at 98 to $101 \mathrm{~cm}$ depth in Sq A 5 assoc with several small bladelets and a medium-sized crescent. Comment: artifacts show relationship with assemblage in Layer F in Apollo 11-Cave, with Howieson's Poort affinities.

KN-2141. Huns

$\mathbf{2 5 0} \pm \mathbf{7 0}$

Charcoal fragments at 10 to $15 \mathrm{~cm}$ depth from test pit excavated in 1974 in shelter on farm Huns $\left(27^{\circ} 25^{\prime} \mathrm{S}, 17^{\circ} 11^{\prime} \mathrm{E}\right), 100 \mathrm{~km} \mathrm{~S}$ of Bethanien, Bethanien dist, SW Africa. Assoc with pottery, glass beads, copper. No rock art is known in or near this shelter. Coll 1974 and subm 1975 by W E Wendt (1975, p 23-29). Comment: dates another site from fairly recent protohistoric phase in southern SW Africa.

$\begin{array}{lllr}\text { KN-I.630. } & \text { A Aar } 1 & -60 \pm 50 \\ \text { KN-I.630. } & \text { B Aar 1 } & 110 \pm 60\end{array}$

Two lumps of charcoal taken separately from same ashy lens in uppermost layer at 5 to $10 \mathrm{~cm}$ depth. From systematic excavation begun 1969 and continued 1972 in a cave, Schlangenhöhle, on farm Aar $\left(26^{\circ} 43^{\prime}\right.$ $\left.\mathrm{S}, 16^{\circ} 31^{\prime} \mathrm{E}\right), 25 \mathrm{~km}$ SE of Aus, Lüderitz dist, SW Africa. Three layers can be distinguished. Samples assoc with potsherds, one tanged iron arrow tip, a few glass beads, a European button, worked ostrich eggshell (beads, engraved fragments) and several microlithic tools. There is a painting in this cave and several rock engravings exist in the vicinity. Sample A coll 1969 and subm 1970; Sample B coll 1972 and subm 1973 by W E Wendt (1972, p 18; 1975, p 23-29). Comment (WEW): microlithic tools in surface layer might have been derived from underlying layer. Different dates for both separately dated samples from same ashy lens are puzzling. Had these 2 samples been combined, still another date might have been obtained. Dates confirm recent age of surface layer which undoubtedly belongs to proto-historic phase in southern SW Africa. Comment (JCF): conventional ${ }^{14} \mathrm{C}$ clate after $1950 \mathrm{BP}$ has, naturally, only a formal meaning, namely that ${ }^{14} \mathrm{C}$ content of sample is formally higher than ${ }^{14} \mathrm{C}$ content of NBS oxalic acid contemporary ${ }^{14} \mathrm{C}$ standard. A calibrated date for this case would be ca AD $1955 \pm 5$. The KN-I.630B date also points to the recent past when corrected for Suess effect.

KN-I.728. Tiras 5

$40 \pm 50$

Charcoal fragments from concentration at 8 to $12 \mathrm{~cm}$ depth in Sq B 3 of 1971 excavation in shelter under huge granite boulders on farm Tiras $\left(26^{\circ} 13^{\prime} \mathrm{S}, 16^{\circ} 34^{\prime} \mathrm{E}\right), 60 \mathrm{~km} \mathrm{~N}$ of Aus, Bethanien dist, SW Africa. Sample from upper of 2 layers assoc with assemblage of typical microlithic tools, worked ostrich eggshell (beads, engraved fragments), several potsherds, fragment of copper bracelet and several pieces of scrap metal on surface. There are several interesting paintings under boulders. Coll 1971 and subm 1972 by W E Wendt (Vogel, ms in preparation; Wendt, 1972, p 2324; 1975, p 23-29). Comment: 2 further samples were dated at Pretoria 
(Pta-1183, -1184) which confirm recent age of upper layer, belonging to proto-historic phase in southern SW Africa. Microlithic tools in this layer might have been derived from underlying LSA layer.

\section{KN-I.634. Uri-Hauchab 4 \\ $40 \pm 50$}

Charcoal fragments from ashy lens at 9 to $11 \mathrm{~cm}$ depth from test-pit excavated in 1969 in a small shelter between large granite boulders in Uri-Hauchab Mts $\left(25^{\circ} 25^{\prime} \mathrm{S}, 15^{\circ} 11^{\prime} \mathrm{E}\right)$, in Namib Desert, Diamond Area 2, SW Africa. Samples assoc with assemblage of common microlithic tool types of LSA, worked ostrich eggshell (beads, engraved fragments) and a few glass beads. More glass beads and a copper bead were on surface. No pottery was found at this site. No rock art is known from this area. Coll 1969 and subm 1970 by W E Wendt (1972, p 16-17; 1975, p 23-29). Comment: also a site belonging to protohistoric phase in southern SW Africa. Indication for survival of microlithic LSA tradition until recently?

\section{Namtib series, SW Africa}

Excavation, 1971, of test trench in shelter on farm Namtib $\left(26^{\circ} 02^{\prime} \mathrm{S}\right.$, $\left.16^{\circ} 15^{\prime} \mathrm{E}\right), 70 \mathrm{~km} \mathrm{~N}$ of Aus, Lüderitz dist, SW Africa. Two distinct, but partly disturbed layers, were found. No rock art is known in or near this shelter. Samples coll 1971 and subm 1975 by W E Wendt. Two other samples from this site were dated at Pretoria (Pta-1185, -1186), (Vogel, ms in preparation; Wendt, 1972, $\mathrm{p}$ 22-23).

KN-2142. Namtib P. 1

$7560 \pm 75$

Scattered lumps of charcoal at 16 to $21 \mathrm{~cm}$ depth in Sq A 3 assoc with poor assemblage, including in this spit one potsherd and a shred of cloth. Comment: spit was believed to be part of upper and fairly recent layer. But this area, like others in shelter must have been disturbed. Sample might have been dug from pit in basal layer since it is ca $2200 \mathrm{yr}$ older than Pta-1186, coll 15 to $25 \mathrm{~cm}$ deeper in same square (reversed stratigraphy). Obviously, it does not date assoc artifacts.

KN-2143. Namtib P. 2

$8230 \pm 70$

Scattered charcoal lumps at 48 to $54 \mathrm{~cm}$ depth in Sq A 4 assoc with a few typical microlithic LSA tools and several ostrich eggshell beads. Comment: sample has been recovered from basal layer and dates LSA assemblage. See also Pta-1185 from site and dates from Layer C in Apollo 11Cave.

\section{Maguams series, SW Africa}

Excavation, 1969, in shelter under huge quartzite block on farm Maguams $\left(25^{\circ} 32^{\prime} \mathrm{S}, 16^{\circ} 52^{\prime} \mathrm{E}\right), 80 \mathrm{~km} \mathrm{~S}$ of Maltahöhe, Maltahöhe dist, SW Africa. Samples coll 1969 and subm 1970 by W E Wendt (1972, p 1718).

General Comment: there are several rock paintings in this shelter, Andalusia, 3 layers were found. A further ${ }^{14} \mathrm{C}$ sample was subm to Pretoria, still pending. 
KN-I.631. Maguams-Andalusia P. 1

Charcoal fragments from concentration at 15 to $17 \mathrm{~cm}$ depth in Sq A 5 assoc with a few potsherds, ostrich eggshell beads and only a few microlithic tools of LSA typology. Comment: dates upper layer containing pottery together with elements of microlithic LSA assemblage.

KN-I.632. Maguams-Andalusia P. 2

$5960 \pm 60$

Charcoal fragments from concentration at 34 to $36 \mathrm{~cm}$ depth in $\mathrm{Sq} \mathbf{A}$ 5. From base of 2nd layer containing LSA assemblage, including peculiar type of microlithic scrapers (mostly in higher horizons of this layer). Comment: dates beginning of LSA occupation in shelter.

KN-I.633. Maguams-Terrace

$3330 \pm 55$

Charcoal from concentration at 92 to $97 \mathrm{~cm}$ depth from test-pit excavated in another shelter, Terrace Shelter, on same farm in 1969. Assoc with poor LSA assemblage comprising several peculiar microlithic tools. There are a few rock paintings in shelter. Coll 1969 and subm 1970 by W E Wendt (1972, p 17). Comment: 1st and, so far, only site in southern SW Africa with LSA assemblage from this period, 5th to 2nd millennium BC, whereas many LSA occurrences in NW SW Africa fall into this period.

\section{B. Sites in NW districts of $S W$ Africa}

KN-I.465. Etemba 2

$1930 \pm 50$

Charcoal lumps from concentration at 52 to $56 \mathrm{~cm}$ depth from test trench excavated in 1968 in rock shelter with paintings on farm Etemba $\left(21^{\circ} 27^{\prime} \mathrm{S}, 15^{\circ} 39^{\prime} \mathrm{E}\right)$, Erongo Mts, $30 \mathrm{~km} \mathrm{~W}$ of Omaruru, Omaruru dist, SW Africa. Assoc with poor ISA assemblage, with only a few typical microlithic tools, worked ostrich eggshell (beads, pendants). Coll 1968 and subm 1969 by W E Wendt (1972, p 10-11). Comment: a number of potsherds were found in horizon 25 to $35 \mathrm{~cm}$ above sample with stone artifacts of LSA typology. Due to general scarcity of potsherds in excavations in SWA so far, lack of potsherds assoc with sample is inconclusive. 2200 to 1800 BP appears to be crucial phase for occurrence of earliest pottery in SW Africa. (See also Omandumba series, below). Previously pub date (Wendt, 1972, Table 2, no. 11) has again been modified.

KN-I.467. Etemba 14

$420 \pm 60$

Scattered charcoal lumps at 10 to $15 \mathrm{~cm}$ depth from trench excavated in 1968 in front of shallow abri with paintings on farm Etemba $\left(21^{\circ} 27^{\prime}\right.$ $\mathrm{S}, 15^{\circ} 39^{\prime} \mathrm{E}$ ), Erongo Mts, $30 \mathrm{~km}$ W of Omaruru, Omaruru dist, SW Africa. Assoc with LSA assemblage, with several typical microlithic tools, worked ostrich eggshell (beads, pendants) and also several potsherds. Coll 1968 and subm 1969 by W E Wendt (1972, p 11). Comment: apparently dates horizon with LSA assemblage with pottery. Previously pub date (Wendt, 1972, Table 2, no. 12) has again been modified.

\section{Omandumba series, $\mathbf{S W}$ Africa}

Systematic excavation, 1968, in shelter, Fackelträger, uncler huge granite boulders on farm Omandumba West (21 $\left.34^{\prime} \mathrm{S}, 15^{\circ} 21^{\prime} \mathrm{E}\right)$, Erongo 
Mts, $40 \mathrm{~km} \mathrm{~W}$ of Omaruru, Omaruru dist, SW Africa. Two distinct layers occurred with traces of MSA occupation at base. Numerous paintings are under boulders. Samples coll 1968 and subm 1969, 1972 by W E Wendt (1972, p 10).

\section{Trench $A$}

KN-I.4 б0. Fackelträger P. 1

$2940 \pm 45$

Large lumps of charcoal at 9 to $11 \mathrm{~cm}$ depth from Sq S 2 assoc with LSA assemblage comprising macrolithic and microlithic artifacts/tools, grooved stones, worked ostrich eggshell (beads, pendants), several bone tools and a number of potsherds. Comment: this "early" date apparently assoc with pottery poses some problems. Because of virtually contemporary date of Sample P.2 from greater depth in same square, Sample P.1 presumably was derived from pit dug into deeper horizon and it subsequently became mixed with younger material, including potsherds (sort of reversed stratigraphy). Previously pub date (Wendt, 1972, Table 2, no. 10) was modified again.

KN-I. 61 . Fackelträger P. 2

$2910 \pm 45$

Scattered charcoal fragments at 28 to $36 \mathrm{~cm}$ depth from Sq S 2 assoc with similar LSA assemblage to Sample P.1, but no pottery was found at this depth throughout entire excavation of Trench A. Comment: although sample was coll at greater depth, it seems to be contemporary with Sample P.1. Did Sample P.2 get into a deeper pit or was Sample P.1 dug up from such a pit? Evaluation of available evidence and observations suggests the latter. Previously pub date (Wendt, 1972, Table 2, no. 9) was modified again.

\section{Trench $B$}

\section{KN-I.729. Fackelträger B.1}

$230 \pm 50$

Scattered lumps of charcoal at 5 to $10 \mathrm{~cm}$ depth from $\mathrm{Sq}$ B 2 assoc with LSA assemblage comprising macrolithic and microlithic artifacts/ tools, worked ostrich eggshell, and a few potsherds. Comment: dates surface horizon of this LSA assemblage, here assoc with pottery.

\section{KN-I.732. Fackelträger B.2}

$2190 \pm 40$

Scattered charcoal fragments at 5 to $15 \mathrm{~cm}$ depth from Sq B 5 assoc with similar LSA assemblage and 1 potsherd. Comment: scattered charcoal fragments as well as artifacts, including the potsherd, were coll from sieve, not in situ. True relationship between sample and sherd within this fairly thick spit is not known. Thus, date should not be regarded as genuinely early date for occurrence of pottery in this part of SW Africa and utmost caution is advisable in interpreting date. Compare comments for KN-I.465 from Etemba 2, above.

KN-I.731. Fackelträger B.3 $2150 \pm 60$

Scattered charcoal fragments at 10 to $25 \mathrm{~cm}$ depth from $\mathrm{Sq} \mathrm{B} 4$ assoc with similar LSA assemblage to Samples B.1 and B.2, but no potsherds 
were found in spit. Comment: because of scarcity of potsherds in excavations done in SWA so far, absence of potsherds in this thick spit is not conclusive. Date puts spit into crucial phase for earliest occurrences of pottery in this part of SW Africa. Compare comments for KN-I.465 from Etemba 2, above.

KN-I.730. Fackelträger B.4.

Scattered charcoal lumps at 25 to $35 \mathrm{~cm}$ depth from Sq B 2 assoc here with only a few artifacts of LSA assemblage. Comment: sample from deepest spit in this sec of Trench B; artifacts are similar to those assoc with Sample P.2 (KN-I.461) from Trench A. Also dates deeper horizon of this LSA assemblage.

\section{Messum Mountains series, SW Africa}

Excavation was made 1968 of cave, Messum 1, in center of Messum Mts $\left(21^{\circ} 22^{\prime} \mathrm{S}, 14^{\circ} 17^{\prime} \mathrm{E}\right), 40 \mathrm{~km} \mathrm{SW}$ of Brandberg, central Namib, Swakopmund dist, SW Africa. Three distinct layers and a "bedding" pit dug into surface were found. There are no rock paintings in cave, but a few are known from another small shelter nearby. Samples coll 1968 and subm 1970 by W E Wendt. Another sample from "bedding" was subm to Pretoria; still pending (Wendt, 1972, p 14-15).

KN-I.636. Messum P. 1

$860 \pm 55$

Charcoal lumps from concentration at 3 to $5 \mathrm{~cm}$ depth in $\mathrm{Sq}$ A 12 assoc with potsherds, some macrolithic and microlithic artifacts/tools and ostrich eggshell beads. Comment: typical microlithic LSA tools found in spit seem to belong to genuine LSA layer immediately below and were probably incorporated into this thin surface horizon. Sample should only be considered for dating pottery at site.

KN-I.637. Messum P. 2

$2070 \pm 90$

Charcoal fragments from concentration at 7 to $9 \mathrm{~cm}$ depth in Sq A 10 assoc with extremely rich, predominantly microlithic LSA assemblage with numerous and varied typical microlithic tools, worked ostrich eggshell (beads, pendants). Comment: much of layer was excavated but no potsherds were found. Layer presumably contains pre-pottery LSA assemblage.

KN-I.639. Messum P.4

$2090 \pm 45$

Scatiered charcoal fragments at 17 to $19 \mathrm{~cm}$ depth from Sq A 10 assoc with deeper horizon of same assemblage as Sample P.2. Comment: although sample was coll at greater depth, it seems to be contemporary with previous one. Whether sample is from deeper horizon or accumulation was rapid at this spot is unresolved.

KN-I.638. Messum P.3

$\mathbf{2 8 2 0} \pm \mathbf{5 5}$

Scattered charcoal fragments at 21 to $24 \mathrm{~cm}$ depth from Sq A 7 assoc with another seemingly similar horizon of microlithic LSA assemblage. Comment: although sample was coll only slightly deeper than Sample 
P.4, it is considerably older. No marked change in sediments were noticed during excavation, and assemblage includes same types of microlithic tools. It is undetermined if there is hiatus between P. 3 and P.4 or if P.4 was from deeper pit in older horizon.

\section{KN-I.635. Austerlitz}

$910 \pm 55$

Charcoal fragments from concentration at 9 to $11 \mathrm{~cm}$ depth from test trench excavated in 1968 in shelter under huge sandstone block on farm Austerlitz $\left(20^{\circ} 25^{\prime} \mathrm{S}, 14^{\circ} 24^{\prime} \mathrm{E}\right), 55 \mathrm{~km} \mathrm{~W}$ of Welwitschia (Khorixas), Outjo dist (Damaraland), SW Africa. Assoc with LSA assemblage comprising several typical microlithic tools, worked ostrich eggshell (beads, pendants) and 1 small potsherd. No rock art is known in area. Coll 1968 and subm 1970 by W E Wendt (1972, p 13-14). Comment: apparently dates horizon of LSA assemblage with pottery.

\section{KN-I.469. Twyfelfontein "Hasenbild"}

$$
\mathbf{3 7 0} \pm \mathbf{5 0}
$$

Charcoal lumps from hearth from surface of partly eroded cultural layer at 8 to $15 \mathrm{~cm}$ depth. Excavation made in 1968 in shelter under huge sandstone block on farm Twyfelfontein $\left(20^{\circ} 35^{\prime} \mathrm{S}, 14^{\circ} 23^{\prime} \mathrm{E}\right), 65 \mathrm{~km} \mathrm{SW}$ of Welwitschia (Khorixas), Outjo dist (Damaraland), SW Africa. Assoc with coarse artifacts, a few small potsherds and a glass bead from surface as well as with typical microlithic LSA tools eroded from deeper layer. Several rock paintings are under this block and numerous rock engravings exist in area. Coll 1968 and subm 1969 by W E Wendt (1972, p 13). Comment: obviously only material on present surface and in hearth (pottery, glass bead) is dated, excluding eroded artifacts from deeper I.SA layer containing assemblage comparable with "Affenfelsen". Previously pub date (Wendt, 1972, Table 2, no. 13) was modified again.

\section{KN-I.468. Twyfelfontein "Affenfelsen"}

Ashy soil at 8 to $13 \mathrm{~cm}$ depth from systematic excavation in 1968 in shelter under huge sandstone blocks on farm Twyfelfontein $\left(20^{\circ} 35^{\prime} \mathrm{S}\right.$, $\left.14^{\circ} 23^{\prime} \mathrm{E}\right), 65 \mathrm{~km} \mathrm{SW}$ of Welwitschia (Khorixas), Outjo dist (Damaraland), SW Africa. Assoc with extremely rich and varied, predominantly microlithic ISA assemblage, comprising numerous typical tools, worked ostrich eggshell (beads, pendants) and various other artifacts. Several rock paintings are under these blocks and some rock engravings are on the blocks; more are in area. Coll 1968 and subm 1969 by W E Wendt (1972, p 12). Comment: dates one of richest and most important LSA assemblages without pottery.

\section{REFFRENCES}

Damon, P E, Lerman, J C, and Long, Austin, 1978, Temporal fluctuations of atmospheric ${ }^{14} \mathrm{C}$ : causal factors and implications: Ann Rev Earth and Planetary Sci, v 6,
p 457-494.

Damon, P E, Long, Austin, and Wallick, E I, 1972, Dendrochronologic calibration of the carbon-14 time scale, v 1, p 44-59, in Rafter, T A and Grant-Taylor, T (cds), 1972, Internatl conf on radiocarbon dating, 8th, Proc, Wellington, New Zealand:
Royal Soc New Zealand.

Faltings, V, 1952, Die Messung natürlicher ${ }^{14} \mathrm{C}$-Aktivitäten im Proportionalzähler: Naturwissenschaften, v 39, p 378-379. 
Faruggia, J P, Kuper, R, Lüning, J, and Stchli, P, 1973, Der bandkeramische Siedlungsplatz Langweiler 2: Bonn, Rheinland Verlag.

Freundlich, J C, 1972, Natural radon as a source of low level laboratory contamination, in Rafter, T A, and Grant-Taylor, T, eds, 1972, Internatl conf on radiocarbon dating, 8th Proc, Wellington, New Zealand: Royal Society of New Zealand, v 2, p 537-546.

1977, ${ }^{14} \mathrm{C}$-Datierung und Dendrochronologie, in Frenzel, 1977, Dendrochronologie und postglaziale Klimaschwankungen in Europa, p 99-114.

Freundlich, J C and Rutloh, M, 1972, Radiocarbon dating by CO, method. Influcnce and removal of known impurities, in Rafter, T A and Grant-Taylor, T, eds, 1972, Internatl conf on radiocarbon dating, 8th Proc, Wellington, New Zealand: Royal Society of New Zealand, v 1, p 133-144.

Hohenschwert, F, 1978, Ur-und frühgeschichtliche Befestigungen in Lippe: Lemgo, Verlag F L Wagner.

Kuper, R, 1975, Der Rössener Siedlungsplatz Inden I: Doctoral dissert, Koeln Univ, $3 \mathrm{v}$.

Lüning, J and Zürm, H, 1977, Die Schussenrieder Siedlung im "Schlösslesfeld": Stuttgart, Verlag Müller und Gräff.

Neustupiny, E, 1970. The accuracy of radiocarbon dating, in Olsson, I U, cd, Radiocarbon variations and absolute chronology, Nobel symposium, 12th, Proc, Uppsala, 1970, p 25: Stockholm, Almquist \& Wiksell.

Olsson, I U, 1970 (ed), Radiocarbon variations and absolute chronology, Nobel symposium, 12th, Proc, Uppsala, 1970: Stockholm, Almqvist \& Wiksell.

1974, The eighth international conference on radiocarbon dating: Geol Fören Stockholm Förh, v 96, p 37-44.

Rafter, T A and Grant-Taylor, T, 1972, Internatl conf on radiocarbon dating, 8th, Proc, Wellington, New Zealand: Royal Soc New Zealand, $2 \mathrm{v}$.

Ralph, E K, Michael, H N, and Han, M C, 1973, Radiocarbon dates and reality: Masca Newsletter, v 9, no. 1, p 1-20.

Schmidt, B, 1977, Der Aufbau von Jahrringchronologien im Holozän mit Eichen aus dem Rhein-, Weser-, und Werre-Gebiet, in Frenzel, B, ed, Dendrochronologie und postglaziale Klimaschwankungen in Europa, p 91-98.

Schwabedissen, H and Freundlich, J C, 1966, Köln radiocarbon measurements I: Radiocarbon, v 8, p 239-247.

1968, Die ${ }^{14} \mathrm{C}-D a t i e r u n g$ von Ehrenstein im Vergleich zu einem Fundplatz der Schussenrieder Kultur, in Zürn, HI, Das jungstein vzeitliche Dorf Ehrenstein, p $105-117$.

Suess, H E, 1970, Bristlecone pine calibration of the radiocarbon time scale $5200 \mathrm{BC}$ to the present, in Olsson, I U, ed, Radiocarbon variations and absolute chronology, Nobel symposium, 12th, Proc, Uppsala, 1970: Stockholm, Almqvist \& Wiksell, p 303-313.

Vogel, J C and Waterbolk, H T, 1967, Groningen radiocarbon dates VII: Radiocarbon, v 9 , p 107-155

Watkins, T, 1975 (ed), Radiocarbon: calibration and prehistory: Edinburgh, University Press.

Wendt, I, Schncekloth, H, and Dudde, E, 1962, Hannover radiocarbon measurements I: Radiocarbon, v 4, p 100-108.

Wendt, W E, 1972, Preliminary report on an archaeological research programme in South West Africa: Cimbebasia, v (B) 2, p 1-61.

1974, "Art mobilier" aus der Apollo-11-Grotte in Südwest-Afrika: Die ältesten datierten Kunstwerke Afrika: Acta Praehist Archaeol, v 5, p 1-42.

1975, Ein Rekonstruktionsversuch der Besiedlungsgeschichte des westlichen Gross-Namalandes seit dem 15. Jahrhundert: S W Africa sci soc Jour, v 29, p 23-56 1976, "Art mobilier" from the Apollo 11 cave, South West Africa: Africa's oldest dated works of art: South Africar archaeol Bull, v 31, p 5-11.

Zürn, H, 1968, Das jungsteinzeitliche Dorf Ehrenstein (Kreis Ulm), v 2: Stuttgart, Staatliches Amt für Denkmalspflege. 